\title{
Male sex predominance in Chlamydia trachomatis sexually acquired reactive arthritis: are women more protected by anti-chlamydia antibodies?
}

\author{
S Bas, C Scieux, T L Vischer
}

\begin{abstract}
Objective-To determine whether the humoral anti-chlamydia antibody response might be related to the ineffective bacterial elimination seen in patients with Chlamydia trachomatis reactive arthritis, particularly in men, who have a higher prevalence of the disease than women.

Methods-The number and specificity of the antibody responses to 27 different $C$ trachomatis antigens were determined by western blots in serum samples from patients with $C$ trachomatis urogenital infection, with and without reactive arthritis, with a special regard to the sex of the patients.

Results-Patients with reactive arthritis had antibodies to significantly fewer chlamydia antigens than those with urethritis only. Antibodies from men recognised significantly fewer antigens than antibodies from women. The IgA class antibodies were slightly more relevant than those of the IgG class for differentiation of patients with reactive arthritis from those with uncomplicated genitourinary infection.

Conclusions-In patients with acute $C$ trachomatis infection the development of reactive arthritis may be related, particularly in men, to a deficient humoral response, to antigens which perhaps play a part in the clearance of the bacteria. Men who cannot generate antibodies to a large number of antigens may be less able to contain the local infection, allowing a wide systemic dissemination of the organisms to the joints.

(Ann Rheum Dis 2001;60:605-611)
\end{abstract}

Rheumatology,

Department of

Internal Medicine,

University Hospital,

Geneva, Switzerland

$S$ Bas

$\mathrm{T} \mathrm{L}$ Vischer

Bacteriology

Laboratory,

Saint-Louis Hospital,

Paris, France

C Scieux

Correspondence to: Dr S Bas, Division of

Rheumatology, Department

of Internal Medicine,

University Hospital, 1211

Geneva 14, Switzerland

bas-sylvette@

diogenes.hcuge.ch

Accepted 23 November 2000
In a small percentage of patients exposure to Chlamydia trachomatis leads to the subsequent development of reactive arthritis. ${ }^{12}$ This disease is more common in men than women, ${ }^{2-6}$ whereas the occurrence of post-enteritic reactive arthritis is nearly equal in both sexes. ${ }^{78}$ The reasons for the male sex predominance are not known. There is little information on $C$ trachomatis immunity in men. Most studies have concentrated on the pathogenesis and immunology of the infection in women because the major morbidity associated with chlamydial disease, in western countries, is the development of infertility resulting from salpingitis.

In patients with $C$ trachomatis sexually acquired reactive arthritis (SARA), protective immunity is inefficient, allowing dissemination of viable bacteria to the joints, as shown by the synovial presence of primary ribosomal RNA transcripts and messenger RNAs. ${ }^{9}$ In patients who do not develop arthritis, we can assume either that the bacteria remain in the urogenital mucosa or are less widely transported to the joints because the bacterium's ability to reach them is a determinant for arthritis induction. ${ }^{10}$ Is the humoral immune response playing a part in protection by preventing systemic bacterial dissemination? Is the humoral immune response comparable in patients developing, and in those not developing, reactive arthritis? What bacterial antigens are recognised by this response? In 1987, Inman et al compared humoral immune responses of men with complicated (Reiter's syndrome) and uncomplicated courses of non-specific urethritis. ${ }^{11}$ An immunoblotting technique did not show any pattern of humoral immune response to $C$ trachomatis characteristic for Reiter's syndrome. However, both groups of patients were not defined as $C$ trachomatis infected, and other micro-organisms (Ureaplasma urealyticum, Mycoplasma, Neisseria gonorrhoeae) might have been present in some patients. We therefore chose to investigate the differences in the serological response between two groups of patients infected with $C$ trachomatis, one with reactive arthritis and one with uncomplicated urogenital infection, and to determine whether this response was related to the sex of the patient. The number and specificity of the antibody responses to 27 different $C$ trachomatis LGV2 antigens were studied after separation of proteins on polyacrylamide gel by immunoblotting techniques.

\section{Patients and methods}

PATIENTS

Serum samples came from our serum collection and had been kept for various lengths of time at $-70^{\circ} \mathrm{C}$. The diagnoses of the patients were taken from their medical charts at the time of collection of the serum samples. The study subjects were categorised in two groups. Group 1 patients $(\mathrm{n}=19)$ had acute $C$ trachomatis SARA: first episode of asymmetrical mono/ oligoarthritis with urethritis and evidence of $C$ trachomatis infection (three had positive findings for urethral/endocervical $C$ trachomatis antigen by direct immunofluorescence, 14 had positive urethral/endocervical $C$ trachomatis cultures, two had positive urethral $C$ trachomatis DNA amplification with the Amplicor test (Roche Diagnostic Systems, Branchburg, NJ)); Table 1 indicates the presence of the HLA-B27 
Table 1 Characteristics of patients with $C$ trachomatis sexually acquired reactive arthritis

\begin{tabular}{|c|c|c|c|c|c|c|c|}
\hline \multirow[b]{2}{*}{ Patient No } & \multirow[b]{2}{*}{ Sex, age } & \multirow[b]{2}{*}{$H L A-B 27$} & \multirow{2}{*}{$\begin{array}{l}\text { Time since onset of } \\
\text { effusion (weeks) }\end{array}$} & \multirow{2}{*}{$\begin{array}{l}\text { Number of } \\
\text { active joints }\end{array}$} & \multicolumn{3}{|c|}{ Number of responses observed in immunoblot } \\
\hline & & & & & $\operatorname{Ig} G$ & $\operatorname{Ig} M$ & $\operatorname{Ig} A$ \\
\hline 18 & $\mathrm{M}, 31$ & + & 3 & 3 & 5 & 1 & 4 \\
\hline 22 & $M, 23$ & - & 19 & 1 & 8 & 0 & 3 \\
\hline 24 & $M, 25$ & + & 8 & 1 & 9 & 4 & 7 \\
\hline 25 & $\mathrm{M}, 32$ & - & 4 & 3 & 10 & 5 & 6 \\
\hline 26 & $M, 26$ & + & 1 & 1 & 11 & 2 & 6 \\
\hline 27 & $M, 25$ & + & 2 & 1 & 7 & 1 & 4 \\
\hline 28 & $M, 55$ & + & 6 & 4 & 4 & 2 & 6 \\
\hline 31 & $M, 18$ & + & 9 & 2 & 9 & 1 & 3 \\
\hline 36 & $\mathrm{M}, 31$ & ND & 8 & 2 & 8 & 3 & 4 \\
\hline 37 & $M, 20$ & + & 26 & 1 & 19 & 2 & 1 \\
\hline 38 & $M, 23$ & + & 9 & 4 & 4 & 0 & 3 \\
\hline 39 & $\mathrm{M}, 28$ & - & 1 & 1 & 9 & 1 & 4 \\
\hline 40 & $M, 23$ & - & 11 & 5 & 21 & 1 & 7 \\
\hline 20 & F, 19 & - & 2 & 2 & 17 & 2 & 5 \\
\hline 23 & $\mathrm{~F}, 27$ & + & 1 & 2 & 10 & 0 & 8 \\
\hline 32 & $\mathrm{~F}, 21$ & ND & 7 & 2 & 11 & 2 & 6 \\
\hline 33 & $\mathrm{~F}, 38$ & - & 3 & 2 & 11 & 4 & 9 \\
\hline 34 & $\mathrm{~F}, 35$ & + & 1 & 3 & 23 & 1 & 20 \\
\hline 35 & $\mathrm{~F}, 36$ & ND & 1 & 1 & 21 & 4 & 14 \\
\hline
\end{tabular}

antigen, time since onset of effusion, and the number of active joints for each patient. Group 2 patients $(\mathrm{n}=42)$ had acute $C$ trachomatis urogenital infection: positive findings on urethral/ endocervical $C$ trachomatis DNA amplification with the Amplicor test. They were recruited from a sexually transmitted diseases clinic. They were examined by a general practitioner/ urologist and were considered not to have arthritis because they did not complain about joint pain.

At the time of serum collection, patients from both groups were not being treated except for those who received non-steroidal antiinflammatory drugs.

Table 2 gives the median ages (in years), age range, and percentages of female subjects, for each group.

MEASUREMENTS OF SERUM IgG, IgM, AND IgA BY AN ENZYME LINKED IMMUNOSORBENT ASSAY Measurements of serum $\operatorname{IgG}, \operatorname{Ig} M$, and $\operatorname{IgA}$ were performed as previously described. ${ }^{12}$

\section{SDS-PAGE AND IMMUNOBLOTS}

Sample preparation

Elementary body antigens of $C$ trachomatis LGV2 strain 434 were purchased from Biodesign International, Kennebunk, ME. These antigens were suspended $(0.72 \mathrm{mg}$ protein $/ \mathrm{ml})$ (bicinchoninic acid protein assay) in sample buffer (0.0625 M Tris-HCl, pH 6.8, $0.0005 \mathrm{M}$ phenylmethylsulphonylfluoride, $10 \%$ (vol/vol) glycerol, $2 \%$ (wt/vol) sodium dodecyl sulphate (SDS), $0.0025 \%$ (wt/vol) bromophenol blue, $2.5 \%$ ( $\mathrm{vol} / \mathrm{vol}$ ) 2-mercaptoethanol), heated to $100^{\circ} \mathrm{C}$ for five minutes, and centrifuged at $10000 \mathrm{~g}$ for five minutes.
Antigen electrophoresis

Precast Tris-glycine polyacrylamide gels (10$27 \%$ with a $4 \%$ stacking gel; $2 \mathrm{D}$ well, $8 \mathrm{~cm} \times 8$ $\mathrm{cm} \times 1 \mathrm{~mm}$ ) were purchased from Novex, San Diego, CA. Two hundred microlitres of antigen sample (145 $\mu \mathrm{g}$ of protein) were loaded in the $2 \mathrm{D}$ well. Two microlitres of Novex prestained, multicoloured protein standard were loaded in the small well. Electrophoresis was performed for 120 minutes at a constant voltage of $125 \mathrm{~V}$ in an Xcell II vertical slab gel system (Novex). The running buffer consisted of $0.025 \mathrm{M}$ Tris, $0.192 \mathrm{M}$ glycine, $0.1 \%$ (wt/vol) SDS, $\mathrm{pH} 8.3$.

\section{Immunoblotting}

$C$ trachomatis antigens were transferred to a Hybond C-extra nitrocellulose membrane (7 $\mathrm{cm} \times 8 \mathrm{~cm}$ ) purchased from Amersham, England. The transfer was performed for one hour at a constant voltage of $40 \mathrm{~V}$ by semi-dry blotting in an Xcell II blot module (Novex) at room temperature. The transfer buffer consisted of $0.012 \mathrm{M}$ Tris, $0.096 \mathrm{M}$ glycine, $20 \%$ (vol/vol) methanol, $\mathrm{pH}$ 8.3. Efficient and homogeneous protein transfer was checked by silver staining.

\section{Antigen detection}

The blotted nitrocellulose membrane was cut into strips $4 \mathrm{~mm}$ in width, which were incubated overnight at $4^{\circ} \mathrm{C}$ in phosphate buffered saline (PBS) with 5\% (wt/vol) bovine serum albumin (BSA) and $0.0003 \mathrm{M} \mathrm{NaN}_{3}$ to block unspecific binding sites. The strips were washed four times for five minutes each time in PBS with $0.05 \%$ (vol $/ \mathrm{vol}$ ) Tween 20 (PBSTween) and incubated for two hours at $37^{\circ} \mathrm{C}$ in sera diluted 1:100 in PBS-Tween. The strips

Table 2 Number of humoral immune responses to Chlamydia trachomatis LGV2 antigens in infected patients with and without reactive arthritis

\begin{tabular}{|c|c|c|c|c|}
\hline & \multirow[b]{2}{*}{ Age (years)* } & \multicolumn{3}{|c|}{ Number of responses observed in immunoblot } \\
\hline & & $I g G$ mean $(S D)$ & $I g M$ mean $(S D)$ & IgA mean $(S D)$ \\
\hline $\begin{array}{l}1 \text { Chlamydia trachomatis sexually acquired reactive arthritis }(\mathrm{n}=19) \\
\text { No }(\%) \text { of female patients }\end{array}$ & $\begin{array}{l}26(18-55) \\
6(32)\end{array}$ & $11.4(5.9)$ & $1.9(1.5)$ & $6.3(4.4)$ \\
\hline $\begin{array}{l}2 \text { Chlamydia trachomatis urogenital infection }(\mathrm{n}=42) \\
\text { No }(\%) \text { of female patients }\end{array}$ & $\begin{array}{l}27(17-55) \\
15(36)\end{array}$ & $17.4(6.2)$ & $2.8(1.9)$ & $11.0(5.5)$ \\
\hline Student's $t$ test between groups 1 and 2 & & $\mathrm{p}<0.001$ & NS & $\mathrm{p}<0.002$ \\
\hline
\end{tabular}

\footnotetext{
${ }^{\star}$ Median (range).
} 


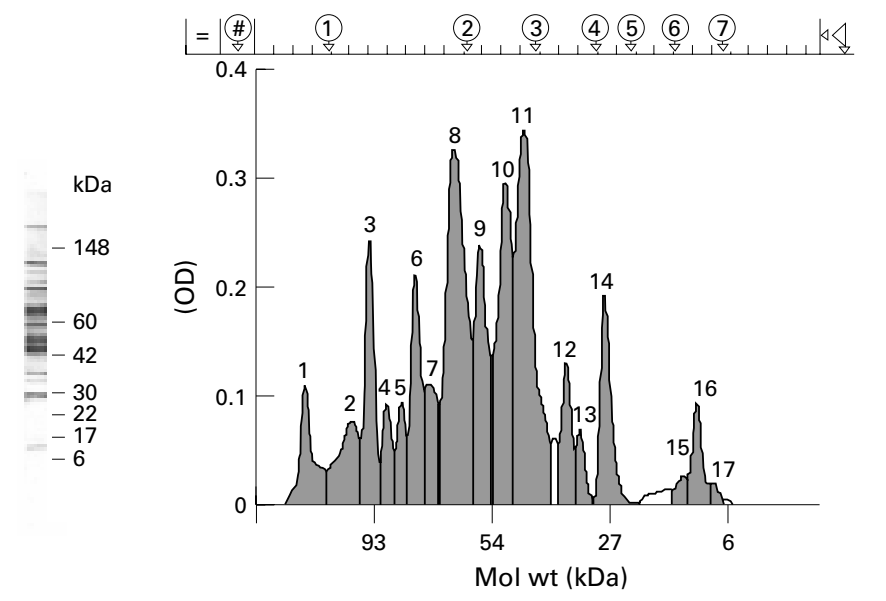

$\begin{array}{cccccc}\text { Area name } & \begin{array}{c}\text { Location } \\ (\mathrm{mm})\end{array} & \begin{array}{c}\text { Area } \\ \left(\mathrm{OD}^{\star} \mathrm{mm}\right)\end{array} & \begin{array}{c}\% \text { Of total } \\ (\%)\end{array} & + & \begin{array}{c}\text { Calculated } \\ \text { mol wt } \\ (\mathrm{kDa})\end{array} \\ 1 & 14.2 & 0.1386 & 3.92 & + & >148 \\ 2 & 18.27 & 0.1554 & 4.4 & + & 105 \\ 3 & 19.74 & 0.2076 & 5.88 & ++ & 95 \\ 4 & 21.17 & 0.0816 & 2.31 & + & 87 \\ 5 & 22.43 & 0.0767 & 2.17 & + & 81 \\ 6 & 23.6 & 0.1973 & 5.59 & ++ & 76 \\ 7 & 24.7 & 0.1279 & 3.62 & + & 72 \\ 8 & 26.96 & 0.6364 & 18.02 & ++++ & 64 \\ 9 & 29.06 & 0.2974 & 8.42 & ++ & 57 \\ 10 & 31.29 & 0.3919 & 11.1 & ++++ & 50 \\ 11 & 32.84 & 0.6097 & 17.27 & ++++ & 45 \\ 12 & 36.41 & 0.1179 & 3.34 & + & 36 \\ 13 & 37.55 & 0.0583 & 1.65 & + & 33 \\ 14 & 39.65 & 0.1975 & 5.59 & ++ & 28 \\ 15 & 46.28 & 0.0251 & 0.71 & + & 14 \\ 16 & 47.5 & 0.0849 & 2.4 & + & 11 \\ 17 & 48.89 & 0.0145 & 0.41 & + & 8\end{array}$

Figure 1 Example of immunoblot analysis. Each immunoblot was evaluated independently with a GS-700 imaging densitometer and the Molecular Analyst software, version 2.1 (Bio-Rad Laboratories, Hercules, CA). The apparent molecular weight (mol wt) of all distinguishable bands was determined by interpolation from the lanes obtained with a commercially available mol wt marker (range 250 to $4 \mathrm{kDa}$ ). A quadratic regression method was used to calculate a standard curve: the y axis displayed the relative mobility (Rf) values of the mol wt standards and the $x$ axis displayed the corresponding mol wt.

were then washed $4 \times 5$ minutes and incubated for two hours at $37^{\circ} \mathrm{C}$ with the alkaline phosphatase conjugated $\mathrm{F}\left(\mathrm{ab}^{\prime}\right)_{2}$ fragment of polyclonal goat IgG antihuman IgG ( $\mathrm{Fc}$ specific), $\operatorname{IgM}$ ( $\mu$ chain specific), or $\operatorname{IgA}(\alpha$ chain specific) diluted with PBS-Tween containing 5\% (wt/vol) BSA. The strips were rinsed twice and washed $4 \times 5$ minutes in PBSTween and then rinsed $2 \times 2$ minutes in the predetection buffer $(0.1 \mathrm{M}$ Tris $\mathrm{HCl}, \mathrm{pH} 8.8$, $\left.0.1 \mathrm{M} \mathrm{NaCl}, 0.005 \mathrm{M} \mathrm{MgCl}_{2}\right)$. The colour was developed by adding the predetection buffer containing $0.35 \mathrm{mM}$ BCIP (5-bromo-4chloro-3-indoyl phosphate) and $0.046 \mathrm{mM}$
NBT (nitroblue tetrazolium) in the predetection buffer. Colour development was stopped by washing the membrane with water after 5-10 minutes.

\section{Analysis of immunoblots}

To avoid biases due to limitations of reproducibility, at least two immunoblots were done with each serum sample and evaluated independently with a GS-700 imaging densitometer and the Molecular Analyst software, version 2.1 (Bio-Rad Laboratories, Hercules, CA). The apparent molecular weight (mol wt) of all distinguishable bands was determined by interpolation from the lanes obtained with a commercially available mol wt marker (range 250 to $4 \mathrm{kDa}$ ). A quadratic regression method was used to calculate a standard curve: the $y$ axis displayed the relative mobility ( $\mathrm{Rf}$ ) values of the mol wt standards and the $\mathrm{x}$ axis displayed the corresponding mol wt. Only the 27 most frequently recognised antigens, with a mol wt range of 117 to $5 \mathrm{kDa}$, were considered. Each antigen was represented by its most commonly observed mol wt ( $\pm 1-2 \mathrm{kDa}$ ) (fig 1$)$. The percentage of patients with serum antibodies against each antigen was calculated.

\section{STATISTICAL ANALYSIS}

Where appropriate, results were analysed by Student's $t$ test and the $\chi^{2}$ test.

\section{Results}

CHARACTERISTICS OF PATIENTS WITH $C$ TRACHOMATIS SEXUALLY ACQUIRED REACTIVE ARTHRITIS

Although the mean time since onset of effusion had a tendency to be shorter for women, no significant difference was seen between male (mean (SD) 8.2 (7.3) weeks) and female (2.5 (2.3)) disease duration and no correlation was found between disease duration and the number of active joints or the number of responses observed in immunoblot. In the same way, no correlation was found between the presence of HLA-B27 antigen and the number of active joints or the number of responses seen in immunoblot, and no correlation was found between the number of active joints and the number of responses observed in immunoblot (table 1).

MEASUREMENTS OF SERUM IgG, IgM, AND IgA

There were no significant differences between patients with and without reactive arthritis in serum IgG (means $14.0 \mathrm{mg} / \mathrm{ml}$ and 12.2

Table 3 Different number of humoral immune responses to Chlamydia trachomatis LGV2 antigens between infected men and women with or without reactive arthritis

\begin{tabular}{|c|c|c|c|c|c|c|c|}
\hline & \multicolumn{3}{|c|}{ Patients without reactive arthritis } & & \multicolumn{3}{|c|}{ Patients with reactive arthritis } \\
\hline & \multirow[b]{2}{*}{ Age $(\text { years })^{*}$} & \multicolumn{2}{|c|}{$\begin{array}{l}\text { Number of responses observed in } \\
\text { immunoblot }\end{array}$} & & \multirow[b]{2}{*}{ Age (years)* } & \multicolumn{2}{|c|}{$\begin{array}{l}\text { Number of responses observed in } \\
\text { immunoblot }\end{array}$} \\
\hline & & $I g G$ mean $(S D)$ & IgA mean (SD) & & & IgG mean (SD) & $\operatorname{Ig} A$ mean $(S D)$ \\
\hline $\begin{array}{l}\text { Men }(\mathrm{n}=27) \\
\text { Student's } t \text { test between }\end{array}$ & $\begin{array}{l}25(17-55) \\
\text { patients without a }\end{array}$ & $\begin{array}{l}15.3(4.2) \\
\text { d with arthritis }\end{array}$ & $9.9(4.3)$ & Men $(n=13)$ & $25(18-55)$ & $\begin{array}{l}9.5(5.1) \\
\mathrm{p}<0.001\end{array}$ & $\begin{array}{l}4.5(1.8) \\
\mathrm{p}<0.001\end{array}$ \\
\hline $\begin{array}{l}\text { Women }(\mathrm{n}=15) \\
\text { Student's } t \text { test between }\end{array}$ & $\begin{array}{l}29(17-54) \\
\text { patients without a }\end{array}$ & $\begin{array}{l}21.3(7.5) \\
\text { d with arthritis }\end{array}$ & $12.8(7)$ & Women $(n=6)$ & $31(19-38)$ & $\begin{array}{l}15.5(5.6) \\
\text { NS }\end{array}$ & $\begin{array}{l}10.3(5.7) \\
\text { NS }\end{array}$ \\
\hline Student's $t$ test between & a men and women & $\mathrm{p}=0.0018$ & NS & & & 0.036 & 0.003 \\
\hline
\end{tabular}

^Median (range). 

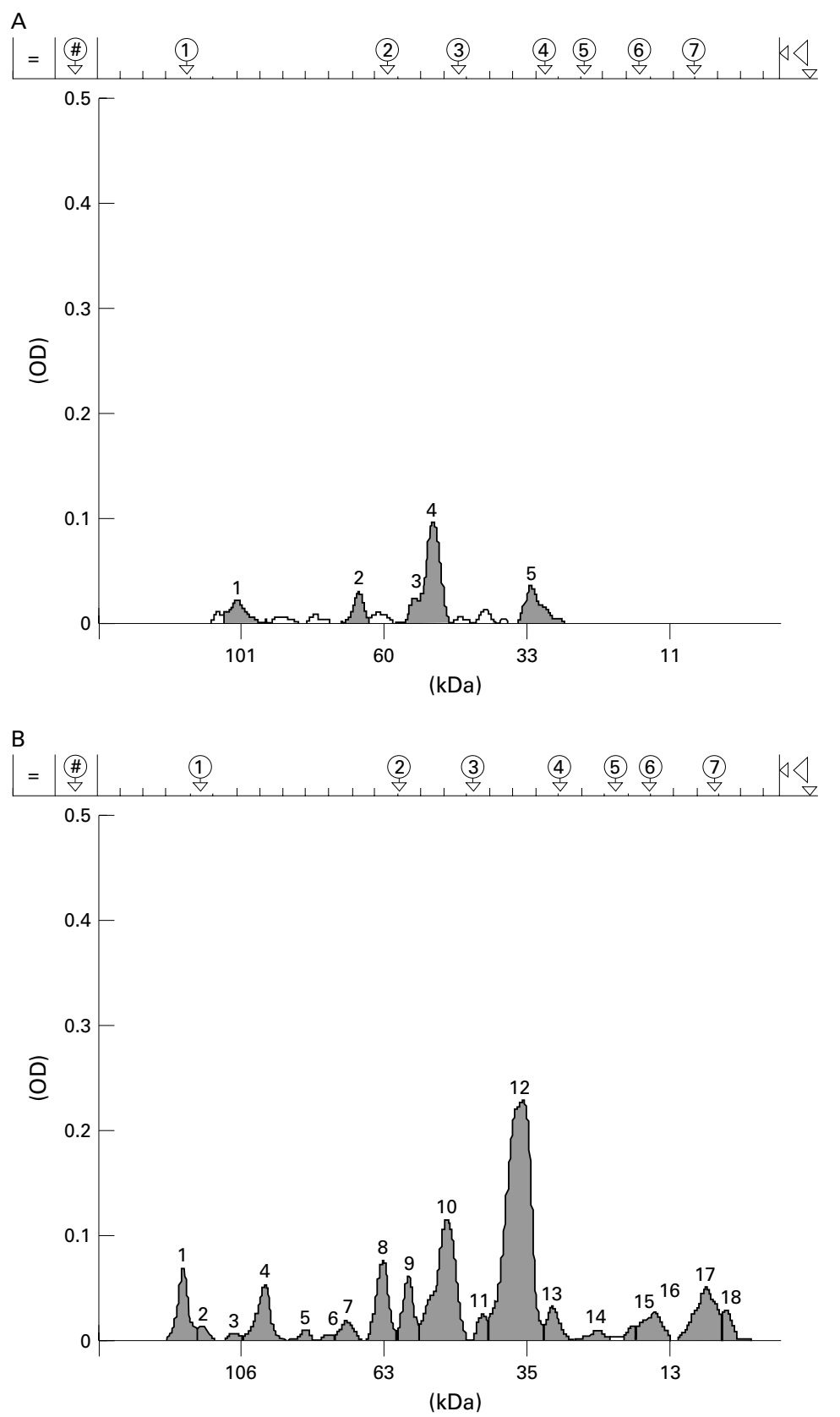

Figure 2 Immunoblot evaluation of IgG responses to $C$ trachomatis antigens, obtained with serum from a man with $C$ trachomatis sexually acquired reactive arthritis $(A)$ and from a non-arthritic man infected with $C$ trachomatis (B).

$\mathrm{mg} / \mathrm{ml}$, respectively), IgM $(0.9 \mathrm{mg} / \mathrm{ml}$ for both groups), and $\mathrm{IgA}(2.4$ and $2.3 \mathrm{mg} / \mathrm{ml})$ concentrations.

NUMBER OF ANTIBODY RESPONSES TO $C$ TRACHOMATIS LGV2 ANTIGENS IN INFECTED PATIENTS WITH AND WITHOUT REACTIVE ARTHRITIS

The mean (SD) number of IgG (11.4 (5.9)) and $\operatorname{IgA}(6.3(4.4))$ responses found by western blot for patients with $C$ trachomatis SARA were significantly lower than for patients with non-arthritic $C$ trachomatis infection (17.4 (6.2) and 11.0 (5.5), respectively) but the number of $\operatorname{IgM}$ responses were not significantly different between the groups (table 2). When the results were expressed according to the sex of the patients, the number of $\operatorname{IgG}(9.5$ (5.1)) and IgA (4.5 (1.8)) responses seen for men with $C$ trachomatis SARA was significantly lower than for women (15.5 (5.6) and 10.3 (5.7), respectively), and the number of IgG responses (15.3 (4.2)) seen for non-arthritic men infected with $C$ trachomatis was significantly lower than for women $(21.3$ (7.5)). The differences in the number of responses between men with $C$ trachomatis SARA and nonarthritic men were significant; for women the differences did not reach significance (table 3 ).

NUMBER OF PATIENTS WITH SERUM ANTIBODY RESPONSES TO THE DIFFERENT LGV2

C TRACHOMATIS ANTIGENS

Different immunoblot patterns were obtained according to the type of sample tested (fig 2). Among the 27 bacterial antigens considered, 13 were recognised significantly more often by antibodies of non-arthritic patients infected with $C$ trachomatis than by those with reactive arthritis, especially by IgA. Seven of them (40, $36,21,18,13,10$, and $6 \mathrm{kDa}$ antigens) were recognised more frequently by both $\mathrm{IgG}$ and IgA and nine of them $(71,40,36,32,27,18$, 13,10 , and $6 \mathrm{kDa}$ antigens) were recognised significantly more frequently by $\operatorname{IgA}$ than by IgG. On the contrary, no antigen elicited a significantly more frequent response in patients with $C$ trachomatis SARA than in non-arthritic patients (table 4).

No pattern of humoral immune response to $C$ trachomatis was found to be specific for patients with $C$ trachomatis SARA.

\section{Discussion}

Our purpose was to analyse carefully the humoral anti-chlamydia antibody response in order to determine whether a deficiency might be involved in the inefficient bacterial elimination seen in patients with reactive arthritis. Indeed, a recent study, using antibody deficient gene knockout mice, showed that both antibody and cell mediated immunity are probably required for resolution of $C$ trachomatis infection. ${ }^{13}$

When the number of antibody responses to 27 different $C$ trachomatis antigens was compared in two populations of infected patients, with and without reactive arthritis, we found that arthritic patients had antibodies to fewer chlamydia antigens than patients with urogenital infection without joint involvement. These deficiencies were more significant for IgA antibodies than for the other isotypes. As IgA is the primary humoral response on the mucosae and $C$ trachomatis infection is mucosa associated, these IgA shortcomings may have a role in the disease development. Indeed, it has been shown that IgA may be the first line of defence against a chlamydial infection, ${ }^{14-16}$ mediating protection from reinfection in animal models. ${ }^{17}$

A study comparing the number of antibody responses to 14 different $C$ trachomatis antigens, in Reiter's syndrome and patients with non-specific urethritis has already been reported by Inman et al. ${ }^{11}$ When we applied a $\chi^{2}$ test to their results, we found that the $78 \mathrm{kDa}$ antigen was recognised significantly more often 
Table 4 Chlamydia trachomatis LGV2 antigens differently recognised by infected patients according to the presence or absence of reactive arthritis

\begin{tabular}{|c|c|c|c|c|c|c|}
\hline \multirow[b]{3}{*}{ Antigens $(k D a)$} & \multicolumn{6}{|c|}{ Percentage of patients with serum antibodies to Chlamydia trachomatis LGV2 antigens } \\
\hline & \multicolumn{2}{|l|}{$\operatorname{IgG}$} & \multirow[b]{2}{*}{$p^{*}$} & \multicolumn{2}{|l|}{$\operatorname{Ig} A$} & \multirow[b]{2}{*}{$p^{*}$} \\
\hline & $\begin{array}{l}\text { Reactive arthritis } \\
(n=19)\end{array}$ & $\begin{array}{l}\text { Urogenital } \\
\text { infection }(n=42)\end{array}$ & & $\begin{array}{l}\text { Reactive arthritis } \\
(n=19)\end{array}$ & $\begin{array}{l}\text { Urogenital } \\
\text { infection }(n=42)\end{array}$ & \\
\hline 99 & 32 & 67 & 0.011 & 21 & 42 & NS \\
\hline 96 & 16 & 49 & 0.011 & 16 & 26 & NS \\
\hline 72 & 16 & 42 & 0.039 & 5 & 21 & NS \\
\hline 71 & 47 & 65 & NS & 21 & 56 & 0.0088 \\
\hline 40 & 21 & 49 & 0.033 & 5 & 42 & 0.0033 \\
\hline 36 & 42 & 79 & 0.005 & 21 & 65 & 0.0018 \\
\hline 32 & 68 & 86 & NS & 21 & 65 & 0.0018 \\
\hline 27 & 37 & 63 & NS & 16 & 51 & 0.011 \\
\hline 21 & 42 & 81 & 0.0024 & 26 & 63 & 0.01 \\
\hline 18 & 53 & 79 & 0.04 & 26 & 74 & 0.0005 \\
\hline 13 & 47 & 86 & 0.0016 & 5 & 77 & $<0.0001$ \\
\hline 10 & 37 & 67 & 0.029 & 16 & 42 & 0.0039 \\
\hline 6 & 32 & 65 & 0.018 & 0 & 33 & 0.0041 \\
\hline
\end{tabular}

${ }^{\star} \chi^{2}$ test between $C$ trachomatis infected patients with or without reactive arthritis.

by IgG and the $32 \mathrm{kDa}$ antigen by IgA from patients with non-specific urethritis, but the 59 and $57 \mathrm{kDa}$ antigens were recognised significantly more often by IgG and IgA from patients with Reiter's syndrome. In the present study we did not find any antigen of about $60 \mathrm{kDa}$ recognised significantly more often by serum antibodies of patients with $C$ trachomatis SARA (IgG $68 \%$; $\operatorname{IgA} 60 \%$ ) than by those of non-arthritic infected patients (IgG $84 \%$; IgA $88 \%$ ). To further examine this point we also determined the IgG responses to a recombinant $C$ trachomatis heat shock protein 60 and found no significant difference in prevalence between patients with and without reactive arthritis (data not shown). This discrepancy between both studies could be explained if some patients with non-specific urethritis were in fact infected by other micro-organisms (Ureaplasma urealyticum, Mycoplasma, Neisseria gonorrhoeae) or if patients with Reiter's syndrome had more chronic disease than our patients with $C$ trachomatis SARA, at the time of serum collection.

To compare validly the humoral immune responses between $C$ trachomatis infected patients with or without arthritis, the time period between $C$ trachomatis infection and serum collection has also to be considered and must not significantly differ between the two groups. Actually, it is impossible to know the infection time, it is only possible to speculate about it. Patients with urethritis only provided serum samples at the time of the acute infection. Published reports show that the incubation period for symptomatic chlamydial urethritis may range from two to 35 days, but it usually lasts from seven to 14 days. ${ }^{18}$ Patients with $C$ trachomatis SARA provided serum samples at the time of the acute arthritis (for the 19 patients, the median duration of disease was four weeks (range 1-26 weeks). Because the minimum interval between the onset of arthritis and the primary infection is thought to be a week and the maximum four to six weeks, ${ }^{19}{ }^{20}$ it is likely that at least some patients with $C$ trachomatis SARA were infected for a longer time than patients without arthritis at the time the serum was drawn. However, if samples from patients with $C$ trachomatis SARA were collected in the declining phase of antibody production a lower number of responses seen in immunoblot should be found in those patients with the longest disease durations (Nos 37, 22, and 40), and this was not the case. In the same way, if samples from patients with urethritis only were provided very early after infection, they would be in the latent phase of antibody production and no specific IgG response would be expected. As no significant difference was found in the number of $\operatorname{IgM}$ responses, both groups of patients were more likely to have been in the exponential or in the steady state phase of antibody production.

When the responses to chlamydia antigens were examined according to the sex of the patients, a higher humoral response was generally seen for women than for men, and this difference was more pronounced for the group of patients with $C$ trachomatis SARA. A higher prevalence of antibodies to $C$ trachomatis in infected women compared with men has already been reported. ${ }^{21-23}$ Although, in the female genital tract, the contribution of antibodies to the protection against ascending $C$ trachomatis infection is under debate. Some studies have shown their potential to reduce the risk and severity of pelvic inflammatory disease $^{24} 25$ and, another, their inefficiency. ${ }^{26}$ Nevertheless, it is unlikely that the local immunity is identical in the male and female urogenital tracts. The more frequent immune responses seen in women compared with men has been partly attributed to the involvement of a larger area of epithelium. ${ }^{27}$ It is also known that women's immune responses are stronger than those of men. ${ }^{28}{ }^{29}$ They have higher immunoglobulin levels and better responses to a variety of antigens. ${ }^{30} 31$ Women generally resist a variety of bacterial infections more successfully than men. ${ }^{32}{ }^{33}$ This sex dimorphism is considered to be a result of the effects of sex hormones on the immune system. Androgens exert an inhibitory influence on both humoral and cell mediated immune responses, whereas oestrogens have a dual role-suppressing cell mediated, but enhancing humoral, immune responses. ${ }^{34}$ The androgen effect on immunity may be more marked in HLA-B27 positive subjects (host factor reported to be present in 
about $45 \%$ of patients with $C$ trachomatis reactive arthritis ${ }^{35}$ ), because this antigen is associated with high testosterone concentrations in men. ${ }^{36}$

The reduced production of antibodies, found particularly in male arthritic patients, may also indicate a polarisation towards a proinflammatory, Th1-type response, with a decrease of immunoglobulin inducing mechanisms. As, during the extracellular phase, elementary bodies are vulnerable to antibody mediated effector mechanisms, a Th2-type response may be crucial in preventing the systemic dissemination of chlamydiae and reducing the number of organisms reaching the joint. Ghaem-Maghami et al have also suggested that, in trachoma, a humoral response may protect against colonisation and limit immunopathological events because chlamydia-specific antibodies were present in children with no evidence of ocular disease, whereas those with the most intense ocular inflammation had almost no antibody production of all isotypes and to all chlamydial antigens considered. ${ }^{37}$

In this study we identified, by their apparent mol wt, 13 bacterial antigens recognised significantly more often by antibodies of non-arthritic patients, but as we do not know their identity, we can only speculate about them. To play a part in antibody mediated effector mechanisms, protective antigens should be immunoaccessible on native elementary bodies. Therefore, the components of the chlamydial outer membrane complex-the lipopolysaccharide (LPS), the major outer membrane protein (MOMP; $40 \mathrm{kDa}$ ), the cysteine-rich outer membrane proteins OMP2 $(60 / 62 \mathrm{kDa})$ and OMP3 $(12.5 \mathrm{kDa})$, and the polymorphic membrane proteins $(98 \mathrm{kDa})^{38}$ may be interesting antigens. However, the antiLPS antibodies are known to be unable to protect against infection. ${ }^{39}$ The main candidate antigen identified as target for neutralisation is the MOMP. ${ }^{40}$ Two other have also been described - the macrophage inhibitory protein, a $27 \mathrm{kDa}$ lipoprotein, ${ }^{25}$ and the heat shock protein $70 .^{41}$ Whether some of these 13 antigens, with appropriate apparent mol wt, might be one of them is only speculative.

From the present study, the humoral immune response in $C$ trachomatis reactive arthritis does not appear to be similar to the response seen in yersinia reactive arthritis. Indeed, in yersinia infected patients, the immunoblotting analyses were similar in non-arthritic and arthritic patients, ${ }^{42}{ }^{43}$ but when humoral immune responses to Yersinia enterocolitica O: $3^{44}$ or to the released protein of mol wt $36 \mathrm{kDa}^{45}$ were analysed, IgA antibody responses were found to be higher in arthritic than in non-arthritic patients. These different results may be related to a different pathophysiology (higher prevalence in men for $C$ trachomatis SARA, presence of live chlamydia in the joint when enterobacteria seem not to be present in the joint, different responses to antibiotic treatment). ${ }^{46}$

In conclusion, the results presented in this study provide some evidence that patients with $C$ trachomatis SARA may lack protection through humoral immunity because their serum antibodies recognised a lower number of target antigens than those from non-arthritic patients. They may be deficient in mounting an effective immune response, directed to the right components, and thus unable to clear $C$ trachomatis rapidly and without sequelae. Thus chlamydia antigens can be deposited in the joint where they remain as a long term stimulus for cell mediated immune responses. The observation that the amount of chlamydial antigen in the joints of B cell deficient mice is markedly greater than in control animals lends credence to this explanation. ${ }^{47}$ The striking predominance of men in this disease, ${ }^{2-6}$ not seen in post-dysenteric reactive arthritis, may be related to the effect of sex hormones on the local immune response in the early phase of infection. The degree of protection due to antibodies, higher in women than in men, may prevent wide dissemination of the bacteria through the circulation and may protect them from reactive arthritis. Even if women develop the disease, it has a somewhat milder clinical expression. ${ }^{48}$

The technical assistance of Yvette Froment, Ursula Spenato, and Monique Stucker is gratefully acknowledged.

Supported by grant No 32-47299.96 from the Fonds National Suisse de la Recherche Scientifique.

1 Keat AC, Maini RN, Nkwazi GC, Pegrum GD, Ridgway GL, Scott JT. Role of Chlamydia trachomatis and HLA-B27 in sexually acquired reactive arthritis. BMJ 978;i:605-7

2 Keat A, Thomas BJ, Taylor-Robinson D. Chlamydial infection in the aetiology of arthritis. Br Med Bull 1983;39:16874.

3 Vilppula AH, Yli-Kerttula UI, Ahlroos AK, Terho PE. Chlamydial isolations and serology in Reiter's syndrome. Scand J Rheumatol 1981;10:181-5.

4 Taylor-Robinson D, Thomas BJ, Dixey J, Osborn MF, Furr PM, Keat AC. Evidence that Chlamydia trachomatis causes seronegative arthritis in women. Ann Rheum Dis 1988;47:295-9.

5 Khan MA, Kellner H. Immunogenetics of spondyloarthropathies. Rheum Dis Clin North Am 1992;18:837-64.

6 Kvien TK, Glennas A, Melby K, Granfors K, Andrup O, Karstensen B, et al. Reactive arthritis: incidence, triggering Karstensen B, et al. Reactive arthritis: incidence, triggering agents and

7 Khan MA, van der Linden SM. Ankylosing spondylitis and other spondyloarthropathies. Rheum Dis Clin North Am 1990;16:551-79.

8 Masi AT. Do sex hormones play a role in ankylosing spondylitis? Rheum Dis Clin North Am 1992;18:153-76.

9 Gerard HC, Branigan PJ, Schumacher HR Jr, Hudson AP. Synovial Chlamydia trachomatis in patients with reactive arthritis/Reiter's syndrome are viable but show aberrant gene expression [see comments]. J Rheumatol 1998;25: 734-42.

10 Sieper J, Braun J, Kingsley GH. Report on the Fourth International Workshop on Reactive Arthritis. Arthritis Rheum 2000;43:720-34.

11 Inman RD, Johnston ME, Chiu B, Falk J, Petric M. Immunochemical analysis of immune response to Chlamydia trachomatis in Reiter's syndrome and nonspecific urethritis. Clin Exp Immunol 1987;69:246-54.

12 Bas S, Cunningham T, Kvien TK, Glennas A, Melby K, Vischer TL. Synovial fluid and serum antibodies against chlamydia in different forms of arthritis: intra-articular IgA production in chlamydia sexually acquired reactive arthriproduction in chlamydia sexually acq
tis. Br J Rheumatol 1996;35:548-52.

13 Su H, Feilzer K, Caldwell HD, Morrison RP. Chlamydia trachomatis genital tract infection of antibody-deficient gene knockout mice. Infect Immun 1997;65:1993-9.

4 Brunham RC, Kuo CC, Cles L, Holmes KK. Correlation of host immune response with quantitative recovery of Chlamydia trachomatis from the human endocervix. Infect Immun 1983;39:1491-4.

15 Michalek SM, McGhee JR, Kiyono H, Colwell DE, Eldridge JH, Wannemuehler MJ, et al. The IgA response: inductive aspects, regulatory cells, and effector functions. Ann N Y Acad Sci 1983;409:48-71.

16 Schachter J. Overview of Chlamydia trachomatis infection and the requirements for a vaccine. Rev Infect Dis 1985;7: and the 16 .

17 Allen JE, Locksley RM, Stephens RS. A single peptide from the major outer membrane protein of Chlamydia trachothe major outer membrane protein of Chlamydia tracho-
matis elicits $\mathrm{T}$ cell help for the production of antibodies to protective determinants. J Immunol 1991;147:674-9. 
18 McCutchan JA. Epidemiology of venereal urethritis: comparison of gonorrhea and nongonococcal urethritis. Rev parison of gonorrhea and

19 Keat A. Reiter's syndrome and reactive arthritis in perspective. N Engl J Med 1983;309:1606-15.

20 Braun J, Kingsley G, van der Heijde D, Sieper J. On the difficulties of establishing a consensus on the definition of and diagnostic investigations for reactive arthritis. Results and discussion of a questionnaire prepared for the 4th International Workshop on Reactive Arthritis, Berlin, Germany, July 3-6, 1999. J Rheumatol 2000;27:2185-92. 21 Bessho H, Matsumoto A. Comparison of antibody titers to aku Zasshi 1990;64:1024-9.

22 Levett PN. Seroepidemiology of chlamydial infection among a sexually-active population in Barbados. West Indian Med J 1994;43:80-3.

23 Ni AP, Lin GY, Yang L, He HY, Huang CW, Liu ZJ, et al. A seroepidemiologic study of Chlamydia pneumoniae, Shlamydia trachomatis and Chlamydia psittaci in different populations on the mainland of China. Scand J Infect Dis populations on

24 Osser S, Persson K. Postabortal pelvic infection associated with Chlamydia trachomatis and the influence of humoral immunity. Am J Obstet Gynecol 1984;150:699-703.

25 Brunham RC, Peeling R, Maclean I, McDowell J, Persson $\mathrm{K}$, Osser S. Postabortal Chlamydia trachomatis salpingitis: correlating risk with antigen-specific serological responses and with neutralization. J Infect Dis 1987;155:749-55.

26 Johansson M, Schon K, Ward M, Lycke N. Genital tract infection with Chlamydia trachomatis fails to induce protective immunity in gamma interferon receptordeficient mice despite a strong local immunoglobulin A response. Infect Immun 1997;65:1032-44.

27 Treharne JD, Forsey T, Thomas BJ. Chlamydial serology. Br Med Bull 1983;39:194-200.

28 Ansar Ahmed S, Penhale WJ, Talal N. Sex hormones, immune responses, and autoimmune diseases. Mechanisms immune responses, and autoimmune diseases. Mechan

29 Morell V. Zeroing in on how hormones affect the immune system. Science 1995;269:773-5.

30 Butterworth M, McClellan B, Allansmith M. Influence of sex in immunoglobulin levels. Nature 1967;214:1224-5.

31 Eidinger D, Garrett TJ. Studies of the regulatory effects of the sex hormones on antibody formation and stem cell differentiation. J Exp Med 1972;136:1098-116.

32 Hanna EE, Watson DW. Host-parasite relationships among group A streptococci. IV. Suppression of antibody response by streptococcal pyrogenic exotoxin. J Bacteriol 1968;95: $14-21$.

33 Rifkind D, Frey JA. Sex difference in antibody response of CFW mice to Candida albicans. Infect Immun 1972.5: 695-8.

34 Bijlsma JW, Cutolo M, Masi AT, Chikanza IC. The neuroendocrine immune basis of rheumatic diseases. Immunol Today 1999;20:298-301.
35 Glennas A, Kvien TK, Melby K, Overboo A, Andrup O, Karstensen B, et al. Reactive arthritis: a favorable 2 year course and outcome, independent of triggering agent and HLA-B27. J Rheumatol 1994;21:2274-80.

36 James WH. Sex ratios and hormones in HLA related rheumatic diseases. Ann Rheum Dis 1991;50:401-4.

37 Ghaem-Maghami S, Bailey RL, Mabey DC, Hay PE, Mahdi OS, Joof HM, et al. Characterization of B-cell responses to Chlamydia trachomatis antigens in humans with trachoma. Infect Immun 1997;65:4958-64.

38 Mygind PH, Christiansen G, Roepstorff P, Birkelund S. Membrane proteins PmpG and PmpH are major constituents of Chlamydia trachomatis L2 outer membrane complex. FEMS Microbiol Lett 2000;186:163-9.

39 Brunham RC, Peeling RW. Chlamydia trachomatis antigens: role in immunity and pathogenesis. Infect Agents Dis 1994;3:218-33.

40 Batteiger BE, Rank RG, Bavoil PM, Soderberg LS. Partial protection against genital reinfection by immunization of guinea-pigs with isolated outer-membrane proteins of the chlamydial agent of guinea-pig inclusion conjunctivitis. J Gen Microbiol 1993;139:2965-72.

41 Danilition SL, Maclean IW, Peeling R, Winston S, Brunham RC. The 75-kilodalton protein of Chlamydia trachomatis: a member of the heat shock protein 70 family? Infect Immun 1990;58:189-96.

42 Stahlberg TH, Granfors K, Toivanen A. Immunoblot analysis of human IgM, IgG and IgA responses to plasmidencoded antigens of Yersinia enterocolitica serovar O3. J Med Microbiol 1987;24:157-63.

43 Stahlberg TH, Granfors K, Pekkola-Heino K, Soppi E, Toivanen A. Immunoblotting analysis of human IgM, IgG and IgA response to chromosomally coded antigens of Yersinia enterocolitica 0:3. Acta Pathol Microbiol Immunol Scand [C] 1987;95:71-9.

44 Toivanen A, Lahesmaa-Rantala R, Vuento R, Granfors K. Association of persisting IgA response with yersinia triggered reactive arthritis: a study on 104 patients. Ann triggered reactive arthritis: a

45 Stahlberg TH, Heesemann J, Granfors K, Toivanen A. Immunoblot analysis of $\operatorname{IgM}, \operatorname{IgG}$, and $\operatorname{IgA}$ responses to plasmid encoded released proteins of Yersinia enterocolitica in patients with or without yersinia triggered reactive arthritis. Ann Rheum Dis 1989;48:577-81.

46 Sieper J, Braun J. Treatment of reactive arthritis with antibiotics. Br J Rheumatol 1998;37:717-20.

47 Rank RG, Ramsey KH, Hough AJ Jr. Antibody-mediated modulation of arthritis induced by chlamydia. Am J Pathol 1988;132:372-81.

48 Rich E, Hook EW 3rd, Alarcon GS, Moreland LW. Reactive arthritis in patients attending an urban sexually transmitted diseases clinic. Arthritis Rheum 1996;39:1172-7. 